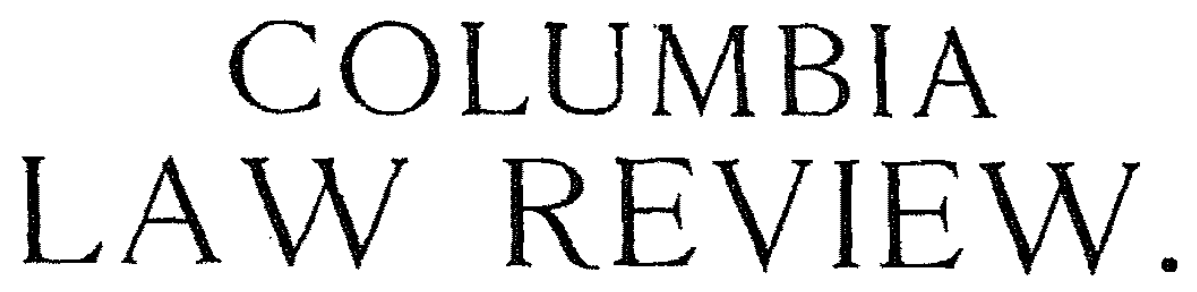

VOL. VIII.

JANUARY, 1908.

No. 1

\title{
THE EARLY HISTORY OF INSURANCE LAW.
}

It seems so highly improbable that the practice of instrance, now deemed indispensable to the safe conduct of commerce on sea or land, should have been unknown to the Phcenicians, Rhodians, Romans and other ancient commercial peoples, that scholars have stbjected ancient writings to the closest scrutiny in the effort to find in them some eviclence that insurances were made in early times. 'The result has been the discovery of accounts of certain transactions which bear such a resemblance to insurance as to have led not a few scholars to the conclusion that insurances were known to the ancients, although the business of underwriting commercial risks was probably not highly developed. Foremost among these writers championing the ancient origin of insurance is Emérigon, whose brilliant and learned Traité des Assurances, first published in $\mathrm{r}_{7} 83$, is still read with respect and admiration by all students of the subject, and cited as authority in the courts of all civilized countries. In this country the same view has been advocated by Justice Duer, whose discriminating and scholarly Lectures on Marine Insurance were published in 1845 , and there are not wanting recent text-writers to reach the same conclusion. ${ }^{x}$ The contention that insurance was known to the ancients rests mainly upon certain passages found in the histories of Livy and Stuetonitis and in the letters of Cicero. Livy tells th that the contractors who tundertook to transport provisions and military stores to the troops in Spain stipulated that the government should assume all risk of loss by reason of perils of the sea or capture. ${ }^{2}$ In the second passage from Livy, ${ }^{8}$ which gives in detail an account

\footnotetext{
${ }^{1}$ E. g., Joyce on Insurance (I897), Vol. I, p. I4.

${ }^{2}$ Livy, lib. 23, c. 49 . "*** * * ut qua in naves imposuissent ab hostium tempestatisve vi publico periculo essent."

${ }^{B}$ Livy, lib. 25, c. 3.
} 
of the extensive frauds practiced by one Postumius upon the cotntry during the Second Punic War by falsely alleging that his vessels, engaged in the public service, had been wrecked, or by making false returns of the lading of old hulks that were purposely wrecked, it seems to be taken as a matter of course that the government was liable to make good such losses.

Suetonius, in his life of Claudius, states that that emperor, in order to encourage the importation of corn, assumed the risk of loss that might befall the corn merchants through perils of the sea. ${ }^{*}$ This passage alone was sufficient to convince Malynes that Claudius "did bring in this most laudible custom of assurances." :

Likewise many writers have thought that Cicero refers to a transaction of commercial insurance when he writer to Caninius Sallust, proquestor, that in his opinion sureties should be procured for any public moneys sent from Ioadicea, in order that both he and the government should be protected from the risks of transportation. ${ }^{\circ}$ These passages of dottbtful significance when read in connection with the well-known fact that the rules of general average, and bottomry and responclentia loans, transactions closely related to insurance, "were familiar to the ancients, have been considered by these writers adequate evidence that insurance was at least known to the commercial peoples of the ancient world.

On the other hand, a great number of writers on insurance

"Suetonius, lib. 5, c. I8. "Nam et uegotiatoribus certa hucra proposuit, suscepto in se damno, si cui quid per tempestates accidisset, el nai's mercaturce causa, fabricantibus magna commoda consitutit."

- Malynes, Lex Mercatoria, (Ist ed., I622) I46.

"Cicero, Epist. ad Fam., lib. II, Epist. I7. "Laodicece me fredes accepturum arbitror omnis pecunia publice, ut ot milhi ct populo cantum sit sine vecture periculo." But the course suggested by Cicero can hardly have been in general use, for, according to Plutarch, when Cato the Younger wished, about the same time, to transport a large sum of public money from Cyprus to Rome he adopted the following curious device to prevent its loss at sea. The money was placed in a large number of small casks, to each of which was attached by means of a long rope, a large block of cork. By this means, we are told, the money was carried to Rome with very little loss.

Tee Moldenhatuer, Das Versicherungswesen, p. 9; Walford, Encyclopadia of Insurance, Vol. I, p. 333. In the speech against Lakritos attributed to Demosthenes, but now thought to have been written by some other Athenian advocate about 34I B. C., there is set forth a bottomry bond which contains provisions for general average contribution, and other terms strikingly like those of a modern bottomry bond. For the provisions of the Roman $\mathrm{L}$ aw governing maritime loans, see $D c$ nattico fenore, Dig. xxii, 2 ; Code, iv, 33 . 
consider that these passages refer to other transactions than insurance, and conclude that insurance was wholly unknown among the ancients. Among these are Grotius ${ }^{8}$ and Bynkershoek ${ }^{\circ}$ on the Continent, and Park, ${ }^{10}$ Marshall and Hopkins in England.

This conflict of opinion as to the practice of insurance among the ancients is due largely to the fact that some writers restrict the significance of the term "insurance" more narrowly than others. The fact that we find no trace of the insurance contract in the laws of Rome or of any of the other ancient peoples, indicates unquestionably that if the contract of insurance, as known in modern times, was known to the ancients at all, its practical use was so little developed as to have made it insignificant. But if the term "insurance" be given a broader significance and made to include any kind of conventional arrangement by which one or more persons assume the risk of perils to which others are exposed-that is, an arrangement for aiding the unfortunatethen it is equally unquestionable that insurance is as old as human society itself. Friendly societies organized for the purpose, among others, of extending aid to their unfortunate members from a fund made up of contributions from all, are as old as recorded history. They undoubtedly existed in China and India in the earliest times. ${ }^{11}$ Among the Greelss these societies, known as Eranoi and Thiasoi, are known to have existed as early as the third century before Christ. ${ }^{12}$ These Grecian societies were largely religious and ritualistic, but among their chief functions, we learn, was that of providing for the expense of fitting burial for members. Similar societies, called Collegia, existed in Rome, where their establishment was attributed to Numa. These also performed many of the functions of benefit insurance societies, providing succor for the sick and aged members, and burial for

${ }^{3}$ Grotius, De Jure Belli et Pacis, ii, 12, 3, 5.

- Bynkershoek, Quast, Juris Pub. i, 2r. "Adeo tamen ille contractus olim fuit incognitus, ut nec nomen ejus, nec rem ipsam in jure Romano deprehendus."

${ }^{10}$ System of the Law of Marine Insurances (1786). This most careful and learned work by Sir James A. Park (afterward Mr. Justice Park of the Common Pleas) is the first orderly treatment in English of the law of insurance. It reflects much of the spirit and genius of Lord Mansfield, with whose whole judicial career the author was personally familiar. (See especially his summary of the argument against the ancient origin of insurance at p. $1 x i, 8$ th ed.).

${ }^{11}$ Walford, Encyc. Ins., Vol. IV, p. 380.

${ }^{12}$ Walford, ibid.; Martin Saint-Léon, Histoire des Corporations de Metiers, p. 23 et seq. 
those deceased. ${ }^{13}$ These Roman Collegia fell into disfavor under the emperors, but nevertheless continued to exist, with restricted functions and influence, up to the time of the fall of the Empire, and it is probable that their existence was continued in spite of the disorder due to the numerous invasions of Italy until they reappeared in history as the mediaval guilds. ${ }^{14}$ Of this, however, there is no documentary proof. It is certain that the guilds, which throughout Europe became so numerous and influential from the eleventh to the eighteenth centuries, possessed very many of the characteristics of the modern muttal benefit association, and, as such, carried on a primitive kind of insurance against the misfortunes incident to sickness and old age. ${ }^{15}$

In England, these guilds existed among the Saxons before the Conquest. We learn that among the purposes of these Saxon guilds was to provide for any member who had had occasion to

${ }^{13}$ Martin Saint-I,éon, I-Iistoire des Corporations de Metiers, p. 24.

At Lantvium, an ancient Latin town about nine miles distant from Rome, there has been found a marble bearing an inscription which sets forth the constitution and regulations of one of these friendly societies in the time of the Emperor Hadrian (A. D. Ix7-138). Parts of this inscription are thus translated:

"An Association (colleginm) constituted uncler the provisions of a decree of the Roman Senate and People, to the honor of Dinna and Antinous, by which decree the privilege is granted of meeting, assembling and acting collectively.

"Anyone desiring to pay a monthly subscription for funeral rites may attend the meetings of the Association; but persons are not allowed, under the color of this Association, to meet more than once a month, and that only for the purpose of contributing for the sepulture of the dead.

"Ye who are desirous of becoming new members of this Association, first read through its laws carefully, and so enter it as not afterwards to complain, or to leave a subject of dispute to your heirs.

"It is absolutely required by the Association that anyone wishing to enter, shall pay an entrance-fee of one hundred sesterces, give an amphora of good wine, and pay as monthly dues five asses.

"Item; It is resolved that whoever shall have omitted to pay his dues for $\frac{1}{1}$ consecutive months, should the fate of humanity befall him, there shall be no claim on the society for his funeral rites, even though he shall have made a will.

"Item; It is resolved that upon the cleath of any nember of this Association who has paid his dues, three hundred sesterces shall be appropriated out of the treasury for him: of which sum fifty sesterces shall be distributed at the burning of the corpse. The funcral procession shall be on foot.

"Item; It is resolved that no funeral rites shall be had by him who, from whatsoever cause, has inflicted denth on himself.

"Item; It is resolved that when any nember of this Association shall be made free, he shall contribute an amphora of good wine."

For the complete inscription see Kenrick's Roman Sepulchral Inscriptions. Also Hopkins' Mantal of Marine Insurance, p. 8.

14 Palgrave's Dict. of Political Economy, Vol. II, p. 209. Guilds.

tis See in general Brentano, The Flistory and Developnent of English 
take the life of anyone, the wergeld, or indemnity that, under the Saxon law, was payable to the family of the person slain. ${ }^{16}$ It seems that these guilds, in addition to providing, by contribution of the members, aid for the sick and burial of the dead among their number, also furnished indemnity to those who had suffered loss by fire. ${ }^{17}$ After the Conquest, the English guilds became numerous and influential. Of one of these, the Guild of St. Katherine, Aldersgate, we learn that the brethren assisted any member if he "falle in poverte, or be aneantised thorw elde or thorw fyr oder water, theves or syknesse." 18 Thus we perceive that what are now termed sick benefit insurance and burial insurance have existed from time inmemorial, and that, while many of the benevolences of these fraternal associations were charitable merely, yet there is to be found in their history distinct evidence of contractual insurance, and even of mutual fire insurance.

In like manner there may be included under the broad definition of insurance given above agreements made by governments, whether through the medium of enactments or through private contract, in accordance with which indemnity is provided for those who suffer loss from peculiar perils. Such just and proper provisions for the protection of the citizen rendering service to the government are doubtless of great antiquity. As stated above, Livy speaks of the practice whereby the Roman Republic indemnified those engaged in transporting military supplies for losses suffered by perils of the sea or acts of the enemy, as one long established and unquestioned. ${ }^{10}$ This undoubtedly was insurance in a limited sense. Indeed, we have evidence that a sort of goverriment insurance was practiced in times much earlier than those of which Livy wrote. In the Code of Hamurrabi, ${ }^{20}$ which must have been enacted at least as early as $2250 \mathrm{~B}$. C., we find a provision that a city in which any man should be robbed of his property should be under obligation to indemnify him for his loss, while

${ }^{10}$ Lambert, Two Thousand Years of Guild Life, p. 43 et seq. Palgrave's Dict. of Political Economy, Vol. II, p. 209.

It is not a very far cry from this savage Saxon form of blood insurance to its modern analogue, employer's liability insurance.

${ }^{17}$ Brentano, The History and Development of English Guilds, P. II; Cheyney, Industrial and Social History of England, p. 72 .

${ }^{13}$ Palgrave's Dict. of Political Economy, ubi supra; Brentano, The History and Development of English Guilds.

${ }^{10}$ Livy, lib. 23, c. 49 ; lib. 25, c. 3 .

${ }^{20} \S \S 23,24$. 
if the city and governor permitted such disorder that a person lost his life, the family of the murdered man were entitled to be indemnified from the public treasury.

Ftrthermore, bottomry and respondentia bonds and the allowing of general average in case of shipwreck and the jettison of the goods of one or more of the joint adventurers, may well be inclucled tunder the term insurance in its broadest significance, and these were unquestionably known and much used among the ancients, particularly among the Rhodians. The lender of money in bottomry who cotrld claim the repayment of his loan only if the vessel upon whose bottom the loan was made completed the contemplated voyage in safety, was entitled, not merely to the current rate of interest on the money loaned, but also to an added sum which would compensate him for the risk he ran of losing his whole principal, and which, in reality, represented the premitum paid tupon the risk assumed. We therefore conclude that the principle of insurance, considered as an arrangement whereby a person subjected to any peril may be indemnified for loss on accotnt of stich peril, was known to the ancients and made use of by them to a very considerable extent; but that commercial insurance, as practiced so extensively in modern times, was either unknown to them or little used.

We are, therefore, safe in concluding that the use of insurance as an important element of commerce and social economy, has had its origin in relatively recent times, but we cannot with any accuracy fix the date of its beginning nor determine indisputably what city or country is entitled to the credit of having originated it. Some scholars have professed to discover evidence that commercial insurance was first developed in Porttgal, while some others favor Spain and Flanders. ${ }^{21}$ More recent research, however, made among the ancient records of the Chamber of Comm merce of Florence has established satisfactorily that insurance had its origin in the great commercial cities of Northern Italy, where it must have been in common use among the merchants engaged in carrying on the large foreign trade of those cities as early as the beginning of the fourteenth century, and possibly

${ }^{22}$ See the statement of these conflicting claims in Il Contratto di Assecuratione nel Medio Evo, by Enrico Bensa, p. 42 ct scq. Richards, in his Insurance (I892), states, without citing authority, that "a Chrmber of Assurance was established in Brtges as early as I3IO." "This can scarcely
be correct. 
more than a century earlier. ${ }^{22}$ Among the records of the Florentine Chamber of Commerce are the books of Francesco del Bene and Company, of Florence, which set forth commercial transactions dating from A.D. I3I8. In these books are recorded the items of expense incident to trade in Flemish cloth and other articles. Among these items one frequently finds the cost of insuring the goods in transit. ${ }^{23}$ From the character of the references to instrances thus made, we can readily infer that as early as I3 8 the custom of making insurances upon goods subject to peril of transportation either on sea or land had become a customary inciclent of traffic. This fact justifies the conclusion that among these Italian cities insurance had been in use many years before the date of the entry in these old Florentine books. The earliest policy of insurance now extant was made in Genoa in the year I347. This quaint old document which, it will be observed, was in the form of a promise to repay a fictitious loan upon the happening of any misfortune to the vessel insured, is set forth in all of its barbarous Latin in the note below. ${ }^{24}$ "The first certain

${ }^{22} \mathrm{Bensa}$, Il Contratto di Assecuratione nel Medio Evo, p. 48. There are unsupported statements to the effect that insurance was invented by the Jews to protect their goods during their flight into Italy after their expulsion from France in II82, and that the Italian merchants learned it from these Jews. See Anderson's History of Commerce, Vol. I, p. 82. The story is inherently improbable. See Duer, Marine Ins., Vol. I, p. 33.

${ }^{23}$ Extracts from Books of Francesco Del Bene e Compagnia di Ferenze, taken from Bensa, II Contratto di Assecuratione nel Medio Evo, p. 183:

"Messer Lapo e Dosso de' Bardi e Compagne devno avere di XVIIII d'Aprile, anno mille trecento dicenove, per rischio di panni inscritti in qua che ci fecero nella fiera di Proino santainolo anno mille trecento diciotto condotti di Fiandra $e$ di Brabante $e$ di Champagnia $e$ di Francia infino a Firenze a tutto loro rischio del costo $e$ delle spese che ci hanno fatte suso ****.

" $i$ quali panni costarono con tutte ispese condotti in Pisa $l$. sei mila novecento quarantasette $\mathcal{e}$ s. diecenove $d$. tre a fiorini che montano a ragnone di lire otto s. quindici centenaio di rischio siccome ne fece patto e mercato, $l$. sei cento septte s. diecenove a fiorino. * * *"

24 "In nomine D. Amen. Ego Georgins Lecavellum civis Janue confiteor tibi Bartholomeo Basso filio Bartholomei me habuisse et recepisse a te mutuo gratis et amore libras centum septem Janue. Renuncians exceptioni dicte pecunie ex dicta causa non habite, non recepte, non numerate et omni juri.

"Quas libras centum septem Janue, vel totidem ejusdem monete pro ipsis, convenio et prometto tibi solemni stipulatione reddere et restituere tibi ant tho certo muncio per me vel meum nuncium.

"usque ad menses sex proxime venturos, salvo et reservato, et hoc sane intellecto, quod si cocha tuo de duabus copertis et uno timono, vocata S. Clara que nunc est in portu Janue parata, Deo dante, ire et navigare presentialiter ad Majorichas iverit et navigaverit recto viagio de portn Janue navigando usque ad Majorichas et ibi applicuerit sana et salva, quod tunc et eo casu sit prasens instrumentum cassum et nullius valoris ut si facta non fuisset. Suscipiens in me omnem risicum et periculum dicte 
record of an insurance transaction at Bruges is of the year I370, but the policy in question was evidently isstued by a Genoese nnderwriter. The earliest trustworthy evidence of the practice of insurance at Barcolona is found in certain ordinances of the City of Barcelona, published in 1435 , which contatin extensive provisions for the regulation of marine insurance. to 'The particularity of these regulations shows dearly that the practice of instrance had already become extensive and of much impurtance in the commercial life of the Catalonian city some time before the date mentioned, but it is hardly probable that it antedited the similar practice in the Italian cities, which, as we have seen, certainly existed considerably more than a entury arlior than the date of the Barcelona ordinances. Anblher positive restim for thinking that instrance was of later developunent in liaredonat than in the Italian cities is found in the earliest extant edition of the Consolat de Mar, known to have been published at litredonat in I494. This celebrated collection of sea litws, which mulere its Italian name of Consolato del Mare, hat for thres centuries stech wide currency throughout Itrope, and which is generally believed to have been first published in Barcelona as early ats the middle of the thirteenth contury, contatins no reference whatever to insurance. ${ }^{27}$

It has been generally believed that the contritet of insurance was first used in tunderwriting marine risks, and it is indisputable that it had its earliest and most important developnnent in comnection with maritime interests. Nevertheless, it is interesting to of-

quantitatis pecunie quonsque dicta cocla aplicutit Majoricis, namignio recto viagio ut supra. Et etiam si dicta cocha fucrit sana it sale'a in aliqua parte, usque ad dictos sex menses, sit similiter prescus insirumentum cassum et mullius valoris, ac si factum non fuisset.

"In dictum modum et sub dictis condilionibus promillo tibi dictom solutionem facere, alioquin penam dupli dicte quantitalis peculic libi stipulanti dare et solvere promitto cum restitutione damnowm et apensarum que propterea fierent vel sustinerentur litis vel extra, ratis manculibus supra dictis et sub ypotheca et obligatione bonorum meorm, habilurum zal habendorum.

"Actum in Janue in Banchis in angulo domus Carli ot Boniface Ususmaris fratrum, anno dom. Nat. MCCCXXXXVII indit. XV secundin cursum Janue die XXIII Octobris circa vesperas. Testes Nicolans de Tacio draperius et Johannes de Recho, flins Bonanali cives Jante" "Printed in Bensa, It Contratto di Assecuratione nel Medio Mvo, p. X92.j

${ }^{23}$ Bensa, Il Contratto di Assecuratione nel Medio Evo, p. 48.

${ }^{20}$ See Walford, Encyc. Ins., Vol. I, p. 25I, where thesc ordintunces are set forth in part. Also Duer, Marine Ins, Vol. I, pp. $34,35$.

sT There is an excellent brief history of the Consolato del Mare, by Sir Travers Twiss, in 9 Encyclopedia Britannica, 317 , and of the other ancient sea laws by the same author in $2 \mathrm{I}$ Encyclopredia Britamica, 583 . 
serve from these ancient books of Francesco del Bene and Company, the Florentine merchants already referred to, that as early as 13 r 8 insurances were customarily made against loss by reason of dangers incident to land transportation, as well as to that by sea, and that shipments of specie were also at that early day insured just as in modern times. ${ }^{28}$

The daring and adventurous merchants of the Italian cities carried on extensive commerce with all of civilized Europe, and during the fourteenth and fifteenth centuries their practice of insuring their ventures spread with their trade to every considerable trading town of the Continent and of England. The usages of insurance, therefore, readily took on the same international character that had already been impressed upon the other customs of traclers engaged in international mercantile pursuits. The t1sages governing the older forms of commerce, especially maritime usages, had found expression in collections of regulations and ordinances of great antiquity, that came to possess the greatest authority throughout Europe rather by their general acceptance than by force of authoritative enactment. These "sea laws," ${ }^{20}$ as they were known, had their origin much earlier than the beginning of the practice of insuring ventures at sea, for otherwise they would not have been silent on so important an adjunct to successful commerce. But their existence undoubtedly greatly facilitated the rapid growth of a body of international insurance customs, which soon became incorporated with the greater body of commercial usages and became an integral part of the law merchant, having the same sanctions and enforced through the same procedure before conventional merchant courts.

As early as $\mathrm{I}_{4} \mathrm{II}$ the business of making contracts of insurance had become of sufficient importance among the Venetians to attract legislative action, for on May ${ }^{5} 5_{\text {th }}$ of that year we find that an ordinance was passed condemning and prohibiting the prevalent practice among Venetian brokers of underwriting foreign risks.

${ }^{28}$ Bensa, Il Contratto di Assecuratione nel Medio Evo, p. 5I. It is hirhly probable that the practice of insurance during the Middle Ages was. not so narrowly confined to marine risks as is generally believed. Nicholas Magens, in his essay on Insurance, published at London, in I755, at p. 267, gives a complete copy of a policy written at Hamburg in 1720 , on the lives of certain cattle. Here we have our very modern live-stock insturance!

${ }^{20}$ The history of these sea laws is very uncertain. 21 Encyciopadia. Britannica, 583. They are collected and translated in Malynes' Lex Mercatoria and Magens' Essay on Instrance, and in Cleirac's Les Us et Coustumes de la Mer, with extensive comments. They are easily accessible to American students in 30 Federal Cases, Appendix. 
But it is evident that underwriters did not at that early day regard insurance regulations with any greater respect than do their successors of the present time, for in June, 1424 , another orclinance again prohibited insurances upon foreign vessels or goods, the preamble carefully explaining that an added reason for not underwriting such risks lay in the fact that war was raging between the Genoese and the Florentines and Catalonians, on which account the Venetians should refrain from aiding any of the belligerents. After this insurance became a favorite stbject for regulation, often of a very drastic character. From the texts of these ordinances it is evident that in Venice the business of underwriting early became localized, $j$ tust as in London it was carried on in Tombard Street, for in these Venetian ordinances it was ustrally provided that they should be read at noon on the "Street of Insurances at the Rialto." 30

In 1435 insurance ordinances, still extant, were published at Barcelona. As already stated, the edition of the Consolat de Mar published at Barcelona in $\mathrm{T} 494$ contained no reference to insurance, nor did the Laws of Wisby or of the Hanse 'Lowns, which, though of earlier origin, were published probably about this same time. It seems that these laws of the northern commercial cities were little more than adaptations of the much earlier laws of Oleron, which likewise make no mention of insurance. In I647 there was published at Bordeaux Cleirac's Us et Coustumes de la Mer, which contained the text of the Guidon de la Mer. This famous treatise on sea laws, which was compiled by some tnknown author of Rouen between the years $1556-1600$, treated extensively of marine insurance. In $x 68 \mathrm{I}$ the Marine Ordinances of L-ouis XIV were published. These ordinances, supposed to be largely the work of Colbert, Louis XIV's gifted Minister of Finance, provide for the regulation of the business of insurance with a completeness of detail that speaks clearly both of the importance of commercial insurance at that time and of the age and extent of the practice that could make such detail possible. Additional evidence of the important place assumed by insurance during the sixteenth century is found in the publication of treatises on insurance by Santerna ${ }^{81}$ in 1552 and by $S$ traccha ${ }^{82}$ in 1569 . The

\footnotetext{
Fo For more complete account of the Venetian ordinances see Hopkins, Marine Ins., p. 20 et seq.

"De "Dssecurationibus et Sponsionibus Mercatorum." Santerna was a distinguished Portuguese lawyer.

\$2: "De Assecurationibus."
} 
excellent treatise of Roccus, an eminent jurist of Naples, was not published until 1655 , much later than the first English treatise by Gerard Malynes, which first appeared in 1622.

The introduction of the practice of insurance into England is shrouded in the same obscurity that envelops its origin on the Continent. Gerard Malynes, in his quaint treatise on the law merchant, published in 1622 , asserts that policies of insurance were written in England at an earlier date than in the low countries, and that in fact Antwerp, then in the meridian of its glory, learned the practice of insurance from London. This conclusion he reached through the wording of the policies issued at Antwerp, which "do make mention that it shall be in all things concerning the said assurances as was accustomed to be done in Lombard Street, in London." Malynes' reasoning is far from convincing, and his conclusion is probably incorrect. It is highly probable, however, that the enterprising Lombards who had taken up their residence in London, in many cases as representatives of Italian trading houses, did not long delay in bringing to England the device of having their commercial ventures assured by underwriters which had proved so advantageous to the trade of their Italian associates. The activity of these London Lombards was so great as to give a name to Lombard Street, ${ }^{88}$ where they dwelt and carried on business as pawn-brokers, goldsmiths and importers of foreign goods. That the introduction of insurance into England is to be attributed to Italians there resident is not only highly probable in itself, but is also supported by much circumstantial evidence. 'Thus one of the clauses of the modern Lloyds' policy provides that the policy "shall be of as much force and effect as the surest writing or policy of assurance heretofore made in Lombard Street." We know also that the earliest policies issued in London of which we have any certain knowledge were written in Italian with English translations attached. ${ }^{\mathbf{3 4}}$

The first certain record of an insurance transaction in England is found in the report of the case of Emerson c. De Sallanova, ${ }^{35}$ determined in a court of admiralty in 1545 . Curiously enough the insurance involved in this proceeding was not against

Malynes explains the name of Lombard Street by saying that "certain Italians of Lombardy kept there a pawn-house or Lombard" [cf. our term "lumber-room"].

${ }^{8 *}$ See Selden Soc. Pub., Vol. XI, pp. 45-58, where several of these policies are given.

${ }^{35}$ Selden Soc. Pub., Vol. XI, p. 1xvi. 
the perils of the sea, as might have been expected, but against possible loss consequent upon the withdrawal by the King of Irance of a safe conduct. The oldest English policy extant, dated September 20, I547, is set forth in both Italian and Iinglish in the report of Broke c. Maynard, an admiralty cause."10 The copy of this policy is much mutilated, but a somewhat similar policy involved in Cavalchant c. Maynard, bearing date only a year later, is found in good condition among the records of the proceedings in admiralty. The English version of this venerable instrument is given in the note below. ${ }^{37}$

It is evident that prior to the time of Lord Mansfictel's accession to the bench, the development of insurance law in Fingland followed the same lines as that of the other branches of the law merchant. It was generally understood that the common law courts, which did not recognize the quasi-international customs of merchants, afforded no fit forum for the determination of causes between merchants. Hence all early insurance disputes must have been settled by conventional merchant courts or arlitrators, who, it seems, might be appointed, tupon petition, by the Privy Council, the Lord Mayor of London, or by the Court of Admiralty. Thus, in the record of the procedings before almiralty prior to 1570 we find a petition by the owner of insured goods asking that arbitrators be appointed and the underwriters made to pay, "and forasmuche as your said rater hath noe remedye by the ordre and course of the common lawes of the realme, and that the ordre of insurance is not grouncled upon the lawes of the realme, but rather a civill and maritime catse to be determined and decided by civilians, or else in the highe courte of Admiraltye." 38

Selden Soc. Pub., Vol. XI, p. 47.

at Selden Soc. Pub., Vol. XI, p. 46.

"In the name of God Amen the XXVIth daye of November, I548.

Thomas Cavalchant and John Gyralde and their company of Jondon make themselves to be assured by the order and accompte of Pauli Ciciny of Messena or of eny other whatsoever they be upon the ship called the Sancta Maria de Porto Salvo patron Matalyno de Maryny or how soo ever better she were called or patronysed upon a hundrithe peaces carscys and fryseys or eny other wares laden or to be laden in ITampton tuntyll they be arryved in Messena and discharged on lancle in good saufty. And the assurers be content that this wrytinge be of as much forse and strength as the best that ever was made or myghte be made in this I,ombard strete of London according to the order and customes whereof every oon that assureth, as they that cause them to be assured or content to be bound. And God sende the good shipp in saufty."

selden Soc. Pub., Vol. XI, p. Ixxvi. 
There were evidently numerous disputes about the payment of insurances, and there were probably many cases in which the underwriters refused to perform the judgments of the merchant courts, whose great weakness lay in the lack of a sheriff, for in the admiralty records for the year $\mathrm{I} 570$ is found a petition on behalf of certain foreign merchants who complained that they could not get their insurance paid. In the same year there was an application by an "Easterling" for the appointment of arbitrators "forasmuche as the matter consistethe muche upon the ordre and usage of merchantes by whom rather than by course of law yt may be forwarded and determyned." It is noteworthy that when the Court of Admiralty made the reference, the commission to hear the case ran to certain English and foreign merchants. ${ }^{39}$

The extracts just given from the admiralty records show that the inability of the conventional merchant courts to enforce their judgments compelled the merchants and underwriters to seek more formal and efficient tribunals before which to bring their causes. They first turned to the courts of admiralty, which easily assumed jurisdiction of maritime and foreign contracts of insurance, and readily took cognizance of the customs of merchants. But for some reason, not easily understood, the courts of admiralty did not prove satisfactory tribunals for the determination of insurance causes, and relatively few of such causes were brought before them. ${ }^{40}$ Lord Coke's misleading report of Crane v. Bell, ${ }^{41}$ a case decided in $\mathrm{I} 546$, has been the source of several mistaken statements that the writ of prohibition granted in that case by a common law court took away from the admiralty courts all jurisdiction of insurance questions. ${ }^{42}$ As a matter of fact, however, Crane v. Bell had nothing to do with insurance, ${ }^{43}$ and we know that admiralty courts still heard insurance cases for nearly half a century after the date of that case. ${ }^{44}$

Whatever may have been the cause, it is clear that the admiralty judges contributed little to the development of insurance law, and that during the latter part of the sixteenth century litigants sometimes felt compelled to carry insurance causes to the

${ }^{80}$ Ibid. $\quad{ }^{40}$ Id., Vol. XI, p. 1.xxx. ${ }^{41} 4$ Coke Inst., I39.

${ }^{42}$ E. g., Bradley, J., in Insurance Co. v. Dunham (I870), II Wall. I, 34.

${ }_{42}$ This is made perfectly clear by Selden Soc. Pub., Vol. VI, pp. lxviii, 129, 229.

${ }^{4}$ E. g., Maye c. Hawkyns (1573), Selden Soc. Pub., Vol. XI, p. 149. In this case the insurer of goods taken by pirates was subrogated to the rights of the insured against Hawkyns, the doughty English admiral, who had recaptured the goods. 
common law courts, in some cases even after they had been heard and determined by merchant courts. Lord Coke's report of Dorem dale's Case ${ }^{45}$ refers to an action brought in a common law court on an insurance policy in 1588 . But manifestly the common law courts of that day, with their highly technical and tedious rules of procedure, as governed by precedents of agricultural rather than mercantile origin, were ill adapted for the settlement of merchants' disputes. Tht1s it appears that at the beginning of the seventeenth century persons having insurance causes were without a satisfactory tribunal for their cletermination. The conventional courts could not enforce their julgments, the courts of admiralty had proved inadequate, possibly because of the vexatious jealousy of the common law cottrts in unreasonibly restricting their jurisdiction, while the common law courts were wholly tuntit. The merchants and underwriters naturally sought relief from Parliament, and secured, in I60I, the first Inglish insurance act, ${ }^{\text {to }}$ "for the obtaining whereof," wrote Malynes," "I have sundry times attended the committees of the said Parliament, by whose means the same was enacted not without some diffenlty; becatse there was [sic] nany stits in law by action of asstumpsit before that time upon matters determined by the Commissioners for Assurances, who for want of power and atthority could not compel contentious persons to perform their ordinances; and the party dying, the assumpsit was accounted void in law." "The preamble of this act is exceedingly interesting, since it not only shows the great importance of the business of instrance at the time of its enactment, and a remarkably clear understanding of the real nature of instrance, but it also gives in striking stmmary the history of insurance law and practice during the preceding century, which necessitated the establishment of the cottrt created by the act. This preamble, in part, is as follows:

"(2) And whereas it hath been time out of mind an usage amongst merchants, both of this realm and of foreign nations, when they make any great adventure, (especially into remote parts) to give some consideration of money to other persons (which commonly are in no small number) to have from them assturance made of their goods, merchandizes, ships and things adventured, or some part thereof, at such rates and in such sort

${ }^{15} 6$ Coke's Rep., $46 \mathrm{~b}$. The case referred to is believed to be the earliest common law insurance case of which any record was made.

43 Eliz., c. I2. ${ }^{47}$ Lex Mercatoria, p. 106 (3rd ed., I686). 
as the parties assurers and the parties assured can agree, which course of dealing is commonly termed a policy of assurance; (3) by means of which policies of assurance it cometh to pass upon the loss or perishing of any ship, there followeth not the undoing of any man, but the loss lighteth rather easily upon many than heavily upon few, and rather upon them that adventure not than those that do adventure, whereby all merchants, especially of the younger sort, are allured to venture more willingly and more freely: (4) and whereas heretofore such assurers have used to stand so justly and precisely upon their credits, as few or no controversies have arisen thereupon, and if any have grown, the same have from time to time been ended and ordered by certain grave and discreet merchants appointed by the lord mayor of the city of London, as men by reason of their experience fittest to understand, and speedily to decide those causes, until of late years that divers persons have withdrawn themselves from that arbitrary course, and have sought to draw the parties assured to seek their monies of every several assurer, by suits commenced in Her Majesty's courts, to their great charges and delays."

By the provisions of this act atthority was given to the Lord Chancellor or to the Lord Keeper of the Great Seal, to issue commissions directed to "the judge of the admiralty for the time being, the recorder of London for the time being, two doctors of the civil law, and two common lawyers, and eight grave and discreet merchants, or any five of them," with authority to hear and determine in a summary manner insurance causes. This court of insurance commissioners did not, however, prove successful, owing to the fact that its jurisdiction was confined to causes arising on policies issued in London, and construed not to extend to any other insurances than those on goods. The court was also held to be open only to the insured and not to the underwriter, and its judgments could not be pleaded in bar to a subsequent action at law. ${ }^{48}$ We are not surprised, therefore, to learn that this special court lapsed into disuse, and died of inanition within a century after its creation.

The failure of this special court seems to have discouraged any further attempts to better an almost intolerable situation, for the hundred and fifty years intervening between the enactment of

48 For the history of the Court of Insurance Commissioners, see Cunningham, Law of Insurances (3rd ed., I766) pp. I63-r69. Also 3 Blackstone's Comm., 74, 75 . 
43 Eliz. and the appointment of Mansfield as Chief Justice of the Court of King's Bench are almost a barren waste as far as the history of the development of insurance law is concerned. The common law judges did not grow in wisclom or in the favor of those having insurance causes. The merchants and underwriters continued to submit their disputes to arbitrators and commissions, sedulously avoiding the common law courts. It is said that, all told, the reported insurance cases determined at law prior to Lord Mansfield's time did not exceed sixty in number, ${ }^{\prime \prime}$ nor among these can there be found one that clearly establishes a great principle or that can be fairly considered a leading case. So slight was the grasp of the common law judges of this period upon the nature and true function of the contract of insurance that as late as 1746 it was uncertain whether an insurable interest was necessary to support a policy, ${ }^{\text {so }}$ although the fundamental principle requiring the presence of stch an interest: was perfectly well understood by the Continental authorities of an enrlier time. In I746, by Statute I9, Geo. II, c. 37, the making of policies without interest was prohibited, as was also the making of reinsurances, under the mistaken impression that they fell under condemnation as wager policies. During this period the doctrine of concentment was applied by the Court of King's Bench in Seaman v. Foncrean, ${ }^{61}$ and the peculiar doctrine of warranties in insurance policies was foreshadowed, rather than definitely declared, in Jeffory v. I,egender, ${ }^{52}$ and in Lethulier's Case. ${ }^{53}$ Add to these a few somewhat uncertain cases on the effect of deviation, ${ }^{54}$ and we have practically the sum of the contributions made to insurance law by common law judges prior to Mansfield.

Lord Mansfield became Chief Justice of the Court of King's Bench in 1756 , which may rightly be considered as the date of the beginning of the development of the modern law of insurance as a part of the common law system. This great judge, thanks to his more liberal Scottish training, was not so slavishly attached to common law precedents as to be unable to perceive the necessity of recognizing merchants' customs in determining rights under

(1) Park, Marine Ins. (4th ed.) xliii.

${ }^{60}$ Compare Depaba $v$. Ludlow (I720) I Comyns 360 , with Goddart $v$. Garrett (Chancery, I692) 2 Vern. 269.

${ }^{51}$ (I743) 2 Strange II83. $\quad{ }^{52}$ (I69r) 3 L,ev. 320.

"s ( 1692$) 2$ Salk. 243.

54 Green w. Young (I702) 2 Salk. 444; Foster $u$. Wilmer (I745) 2 Strange 1249 ; Eilton $v$. Brogden (I746) 2 Strange I264. 
merchants' contracts, not so bigoted as to be unwilling to seek light from foreign sources. In insurance causes, as with causes involving other branches of the law merchant, he impanelled juries of merchants and underwriters, to establish customs and usages current among those who made insurances, and diligently consulted the time-honored maritime laws of the Continent, and the treatises of English and Continental writers. ${ }^{55}$ Thus he not only gave prompt justice to litigants who appeared before him, and provided a fit tribunal for merchants, but he saw so clearly the fundamentals of the theory of insurance, and understood so well its practical applications to the needs of business and commerce, that the numerous doctrines that he laid down have survived all of the many changes in commercial conditions and methods that have since taken place, and almost without exception they apply as well to the commercial transactions of to-day as to those of Mansfield's own time. When he retired from the bench in $x 788$, he left a complete system of insurance law, as is so well shown by Sir James Park, a contemporary of Mansfield's, in his brilliant work on marine insurance. This system has been much extended in modern times, but it has been little changed, and still stands as a lasting monument to the great judge whom Mr. Justice Buller ${ }^{56}$ rightly called "the founder of the commercial law of this country." W. R. VANCE.

THE Grorge WASHINGTON UNIVERSITY.

${ }^{\circ}$ Thus, in Luke $v$. Lyde (I759), 2 Burr, 883,889 , he cites the Rhodian Laws, The Consolato del Mare, The Laws of Oleron and of Wisby, The Ordinances of Louis XIV, and the treatise of Roccus.

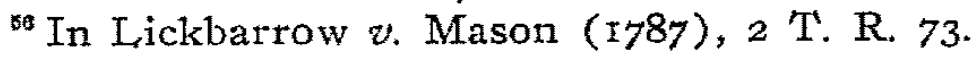

